Quarterly Journal of the Geological Society

\title{
A brief Notice of Organic Remains recently discovered in the Wealden Formation
}

Gideon Algernon Mantell

Quarterly Journal of the Geological Society 1849, v.5; p37-43.

doi: 10.1144/GSL.JGS.1849.005.01-02.14

\section{Email alerting service \\ Permission request}

Subscribe click here to receive free e-mail alerts when new articles cite this article

click here to seek permission to re-use all or part of this article

click here to subscribe to Quarterly Journal of the Geological Society or the Lyell Collection

\section{Notes}

(C) The Geological Society of London 2012 
Somersetshire, where it occupies the same relative position, retains the same mineralogical character, and yields identical fossils. As might be expected, however, in another and more distant portion of the series, there are some genera and several species which have not yet been found in Gloucestershire : these will, I hope, shortly be described by Mr. Moore of Ilminster, their discoverer, whose fine local collection and zealous labours have already brought to light many interesting palæontological and strategraphical facts of novelty and value.

June 14, 1848.

The following communications were read :-

1. A brief Notice of Organic Remains recently discovered in the Wealden Formation. By Gideon Algernon Mantell, Esq., LL.D., F.R.S., F.L.S., Vice-President of the Geological Society.

As our knowledge of the zoology and botany of the islands and continents that flourished during the formation of the secondary strata, can only be extended by a diligent examination of the organic remains that may be discovered from time to time, it appears to me desirable occasionally to record, however briefly, the additions made to the fossil fauna and flora of the Wealden, in the hope of ultimately acquiring data that will afford a satisfactory elucidation of that remarkable geological epoch, "The Age of Reptiles;"- -in which the vertebrated animals that inhabited the land, the air, and the waters, were, with the exception of fishes, almost exclusively of the reptilian type of organization. I therefore submit to the Society the following concise account of the Wealden fossils that have either come under my immediate notice, or of which I have received information from my correspondents, since my last communication on this subject.

Flora of the Wealden.-The additions to the Wealden flora from my own researches consist only of a few more instructive examples of Clathraria and Endogenites than any previously obtained. Specimens of the stem of Clathraria Lyellii, bearing the characteristic cicatrices formed by the attachment and subsequent separation of the petioles or leaf-stalks, have been found at Hastings, at Brook Point in the Isle of Wight, and in the Ridgway cutting near Weymouth. A water-worn fragment of a stem of Clathraria, which I picked up on the sea-shore at Brook Bay, was so much indurated as to render it probable that the internal organization of the original was preserved; but sliced and polished sections made in various directions, when examined under the microscope, only presented such a general indication of the structure as to enable our eminent botanist, Dr. Robert Brown, to pronounce that the essential characters of the Cycadeacea were present, but no close affinity to any known recent genera could be detected. 
A specimen of the internal part of the stem of Endogenites erosa, collected from the same locality, appeared to be solid throughout, and therefore likely to retain the internal structure; but sections made by the lapidary, under Dr. Brown's direction, only showed that the general form and arrangement of the bundles of vascular tissue preserved by mineralization, were more analogous to those which characterize the Cycadeacea than to any other existing plants.

Five or six small cones, of the size of the juli of the larch, and apparently referable to the same species of Abies or Pinus as those found in the greensand of Kent*, have been obtained from the Wealden sands and limestones that emerge on the sea-shore at Hastings and St. Leonard's, and in Sandown Bay in the Isle of Wight; and in each of these localities these fossil fruits were collocated with bones of the Iguanodon and other reptiles.

But although the Wealden of England has proved so barren, that of the North of Germany has yielded a rich harvest to the industry and talents of my friend Dr. Wilhelm Dunker, of Hesse Cassel, who has added to its flora upwards of sixty species of plants; and he informs me that he has discovered several new ones since the publication of his beautiful work $t$. Of these, thirty species, belonging to seven genera, are Ferns, and twelve are referable to $C y c a d e c$ or $Z a$ mia. The British Wealden plants, Endogenites erosa, Sphenopteris Mantelli, Carpolithus Mantelli, and some species of Thuytes or Cupressites, apparently identical with those from Heathfield in Sussex, occur in the same formation in Germany.

The beautiful figures and accurate descriptions of all these plants in Dr. Dunker's work render it unnecessary to particularize them ; I will only remark, that the extensive coal-field of Hanover, which was long since identified with the Wealden by $M$. Roemer, and the numerous plants discovered by Dr. Dunker, prove that the countries of whose debris the Wealden deposits are composed, were clothed with a luxuriant and varied flora, of which arborescent ferns, cycadeæ, and coniferous trees, were the most characteristic and predominant forms.

Fauna of the Wealden.-Of the shells of mollusks, no new species have I believe been detected in England; but the Wealden of Germany has proved as rich in fossils of this class as in vegetables.

Dr. Dunker enumerates upwards of 100 species, comprising Unio $\neq$, 5 species ; Cyrena, 37 species ; Cyclas, 4 species ; Corbula, 4 species ; Melania, 9 species; Paludina, 8 species; Limnea and Planorbis, of each 1 species; and of Ostrea, Exogyra, Avicula, Modiola, Mytilus, Turritella, and Neritina, of each 1 species $\$$.

Crustaceans.-These consist exclusively of the shields or cases of Cyprides and Estheria\|, of which four new species have been

* Quarterly Journal of the Geological Society, vol. ii. p. 54.

+ Monographie der Norddeutschen Weakdenbildung, 1846.

† It may be worthy of remark, that Mr. Barlow, C.E., has discovered specimens of Unio Valdensis (previously known only in the Isle of Wight), in the Wealden of Sussex and Kent.

$\S$ See Dr. Dunker's Monographie der Norddeutschen Wealdenbildung.

If Of Rüppell, ibid. pl. 13. fig. 33, p. 59 . 


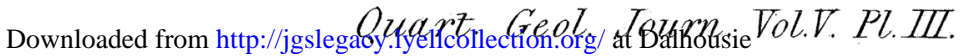
University on December 21, 2012

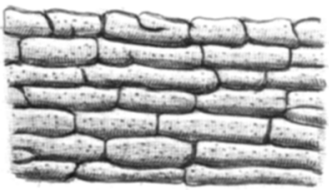

3

\section{highly magnified}

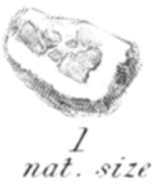

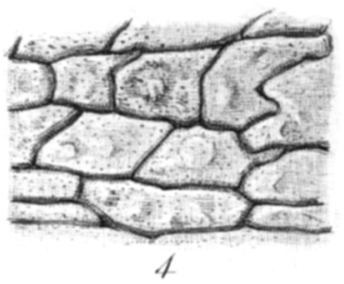
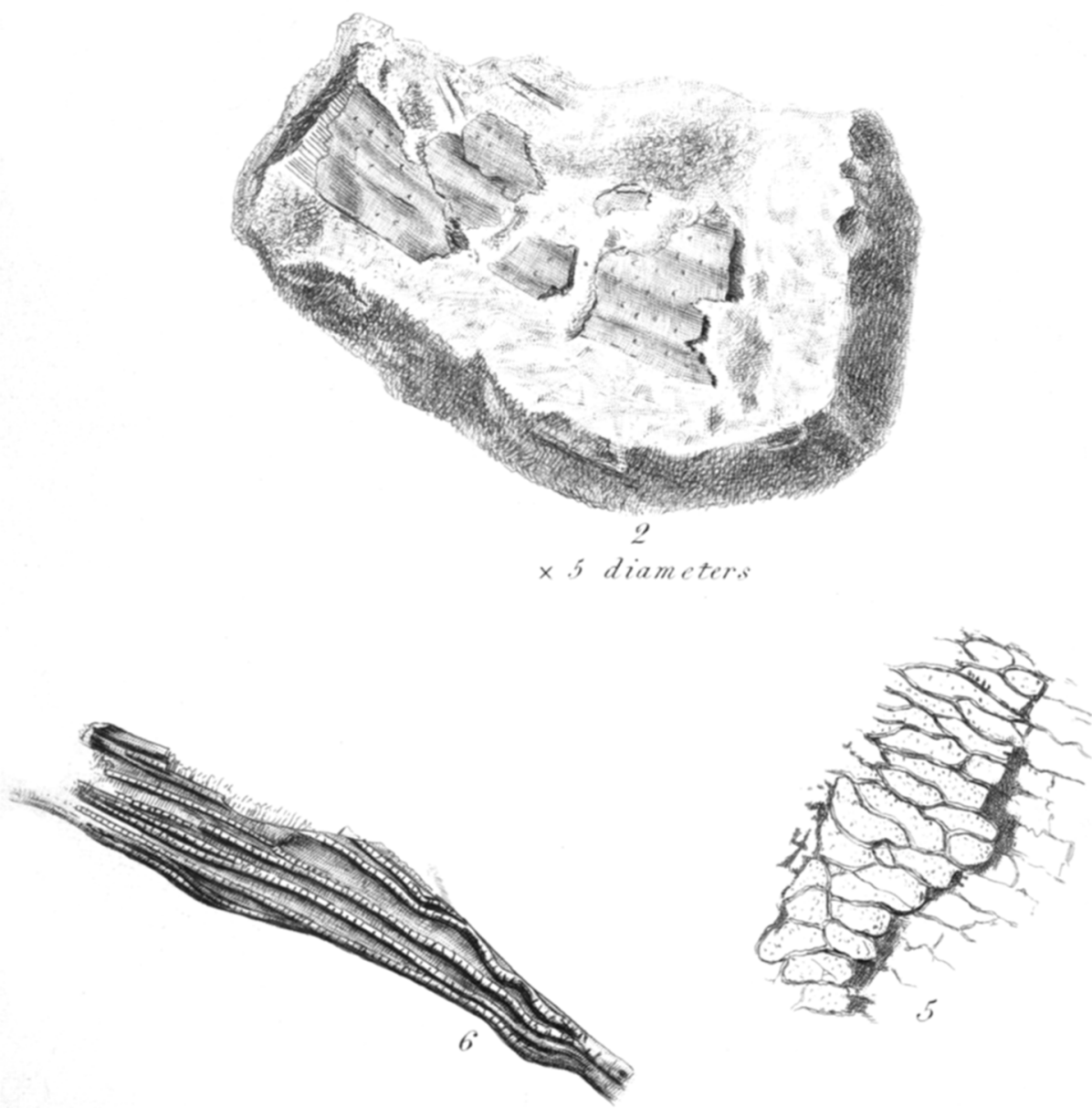
found in Germany. The British fossil Cyprides, first made known by Dr. Fitton, also occur in the Wealden of the North of Germany. The Isopodous crustaceans discovered by Mr. Brodie in the Vale of Wardour have not been found on the continent.

Insects.-To the list of Wealden insects given by the Rev. P. B. Brodie in his interesting work*, I can add no new species; but I am able to corroborate his account of the occurrence of insects in the freshwater strata above the oolite in Buckinghamshire; my friend the Rev. J. B. Reade, and myself, having collected a few specimens from the quarries between Stone and Hartwell. None of these are sufficiently perfect to require remark, with the exception of two fragments of wings, apparently of coleopterous insects, which appear to differ from any figured and described by Mr. Brodie; and as fossils of this kind are very rare, and difficult of detection, I am desirous of preserving faithful representations of these fragile relics. They are accurately figured in the annexed drawings.

Plate III. fig. 1. Fragments of the membranous wing of a small Coleopterous (?) insect, natural size.

Fig. 2. The same, magnified.

Figs. 3, 4, 5. Portions of the same, highly magnified.

Fig. 6. Fragment of another wing, highly magnified.

A few fragments of the elytra of Coleoptera have been observed in the Wealden clays and shales laid bare by the railway-works between Tumbridge and Maidstone.

Fishes. - The Wealden of Germany has yielded one species of Enchodus, two new species of Hybodus, two of Lepidotus, one of Sphrorodus, and one of Gyrodust. The scales and teeth of the two well-known British species of Lepidotus (L. Fittoni and L. Mantelli of Agassiz) appear to be as abundant in Germany as in the S.E. of England. Several splendid examples of the last-named fishes have recently been collected from the rocks exposed along the shore at Hastings, some of which are in the possession of Dr. Harwood of St. Leonard's, and of Mr. Moore of the former place. The entire cranium covered with its plates, the jaws with teeth, and the body enveloped in its rich cuirass of scales, are preserved. Some portions I examined must have belonged to fishes ten or twelve feet in length.

The jaws with teeth, and the crania of Hybodi, as large as the $\boldsymbol{H}$. basanus from the greensand of the Isle of Wight, described by Sir P. Egerton $\ddagger$, have also been obtained. I have not been able to examine these Ichthyolites with the attention necessary to speak positively as to the species, but I have little doubt that some of them belong to the greensand Hybodus; and in fact, the occurrence of several Wealden plants and reptiles in that division of the cretaceous formation, renders it highly probable that similar fishes will be found in both series of deposits.

Reptiles.-Of the colossal terrestrial and aquatic Saurians, whose

* A History of the Fossil Insects of England.

+ Mon. Nord. Wealden. p. 62.

$\ddagger$ Geol. Journal, vol. i. p. 197 . 
remains are so abundant in some of the Wealden strata, numerous detached bones of enormous size have been found at Hastings and St. Leonard's, and in Sandown and Brook Bays in the Isle of Wight; some specimens have also been obtained from the Wealden at Ridgway, by Mr. Shipp of Blandford. The specimens I have examined are, with but very few exceptions, referable to the genera Iguanodon, Hylaosaurus, Megalosaurus, Streptospondylus(?), Pocilopleuron(?), Goniopholis, and Cetiosaurus (?).

Numerous fragments of the bones and carapaces of Chelonians have also been obtained, especially of the remarkable Wealden Trionyx, the T. Bakewelli.

It would be irrelevant to my present object to offer a detailed account of the fossils thus briefly noticed, and I will simply enumerate some of them, as exemplifying the general character of the remains of this class to be met with, along those parts of the coasts of Sussex and the Isle of Wight above-mentioned.

Plesiosaurus: Vertebræ. Hastings, and Brook Bay. Bay.

Cetiosaurus (?): Caudal and sacral rertebræ. Hastings, and Brook

Pocilopleuron(?): Vertebræ. Isle of Wight.

Streptospondylus(?): Cerrical and dorsal vertebræ of large size. Isle of Wight, and Tilgate Forest. Bay.

IIylaosaurus: Vertebræ and dermal bones. Hastings, and Brook

Goniopholis : Teeth. Hastings, Isle of Wight, and N. of Germany.

- Vertebræ, and a portion of the cranium (?).

Macrorhynchus: The cranium of a reptile of the gavial type, thus named by Dr. Dunker from its extremely elongated snout, has been found in the Wealden of Germany near Bückeberg*.

Iguanodon.-The remains of this genus of herbivorous terrestrial reptiles are more abundant in the Wealden strata of the south-east of England and of the Isle of Wight, than those of any of the other saurians. Among the specimens found last year in Brook Bay were two femora, each of which when entire must have been four feet in length; dorsal vertebræ five and a half inches in the antero-posterior diameter; several teeth ; dermal tubercles or horns; ungueal bones of a more depressed form than those in the Maidstone specimen; fragments of the sacrum, and of ribs of large size, \&c.

At Hastings numerous bones have been collected during the last two years, having for the most part been washed out of the ledges of rock by the action of the waves, the agency by which almost all the bones from this locality, and from the Isle of Wight, are brought to view. In the cabinets of Dr. Harwood, Mr. Moore, and other local collectors, I have seen bones of the Iguanodon of great magnitude. The lower extremity of a femur measures forty-one inches in circumference at the condyles, and exceeds in magnitude by nearly one-third

* Mon. Norddeutschen Wealden. tab. 20. Another genus of Saurians has also been proposed by Meyer, from part of a vertebral column with ribs from near Harrel, and named Pholidosaurus.-Ibid. p. 71, tab. 17, 18, 19. 
the largest example in the British Museum. Teeth of this reptile are very rarely found at Hastings.

Upper and lower jaw of the Iguanodon.-But the specimen of the highest interest that has been lately discovered is a considerable portion of the lower jaw of an adult Iguanodon with three successional teeth in place, obtained from a quarry in Tilgate Forest by Capt. Lambart Brickenden, F.G.S., to whose liberality and ardent love of science I am indebted for it. This fossil consists of the right dentary and opercular bones; it is twenty-one inches long, and when perfect must have been two feet in length. According to the proportions of the maxillary elements in the Iguana, the entire length of the jaw to which this specimen belonged was four feet. Two successional teeth, and vestiges of a third, remain in their natural situation, within the internal alveolar parapet; and there are sockets, or rather excavations, for nineteen or twenty mature teeth in the outer wall of the alveolar process. The implantation of the teeth was intermediate between the pleurodont and thecodont types.

As this specimen is the first unequivocal example of the lower jaw of an Iguanodon hitherto known, it is of the highest interest in a palæontological point of view. A fragment of the upper jaw-the anterior part of the left maxillary bone-discovered by me, and now in the British Museum, interpreted by the aid afforded by this recent acquisition, has enabled me, with the valuable assistance of that eminent comparative anatomist, Dr. A. G. Melville, to obtain some important and very unexpected results. But as I have laid before the Royal Society, in whose Transactions my first memoir on the teeth of the Iguanodon was published in 1825, a full account of the anatomical characters of the maxillary and dental organs of this reptilian herbivore, and the physiological deductions resulting therefrom, I will only briefly notice a few of the most striking peculiarities.

In the Iguanodon, the true saurian type of structure is manifested in the mode of implantation and constant reproduction of the teeth, and in the composite construction of the lower jaw, each ramus consisting of six pieces. But the teeth of the upper and lower maxillæ are placed in a reversed position in relation to each other, as in the Ruminants; the enamelled coronal facets of the lower series facing the inside of the mouth, and those of the upper the outside. From the appearance of the abraded coronal portion of the used molars, it is evident that the teeth of the opposite jaws were arranged subalternately or intermediately, for the grinding surface of each tooth presents two facets, from the attrition of two antagonist teeth.

Another most extraordinary modification of structure is presented by the anterior part of the dentary bone; and it is one that could not have been predicated from any thing previously known as to the maxillary organization of reptiles. The symphysial portion, or front of the lower jaw, instead of being crested by the alveolar process beset with teeth, and continued uninterruptedly round the mouth, as in existing lizards, is edentulous, and contracted in a vertical direction, extending horizontally, and uniting by suture with the opposite side. Thus the two rami form by their union an expanded scoop-like pro- 
PROCEEDINGS OF THE GEOLOGICAL SOCIETY. [June 14,

cess, which very closely resembles the corresponding part in the Sloths, and especially that of the extinct colossal Edentata-the $\mathbf{M y -}$ lodons. The dental canal is very large, and the number and size of the vascular foramina sent off from it, and opening on the outer surface of the lower jaw, and along the symphysis, indicate the great development of the lower lip, and of the soft parts and integuments that invested the jaw.

The physiological inferences suggested by this configuration of the dentary bone are in perfect harmony with those derived from the structure of the teeth, and we have now unquestionable proof that the Iguanodon, like the colossal Edentata, possessed a large prehensile tongue and fleshy lips, capable of being protruded and retracted; these must have formed most efficient instruments for seizing and cropping the foliage and branches of the ferns, cycader, and coniferous trees, which doubtless constituted the food of this saurian representative and predecessor of the great herbivorous mammalia.

The true characters of the maxillary organs of the Iguanodon being thus established, I have been able to determine with more precision the nature of several fragments of bones, which were temporarily referred to that animal. The portion of a lower jaw of a small lizard from Tilgate Forest, described by me in the Philosophical Transactions for 1841 as probably that of a young Iguanodon, is evidently subgenerically, if not generically, distinct, though clearly belonging to the same remarkable family. This saurian I therefore now propose to distinguish by the name of Regnosaurus*, to indicate the district in which it was discovered; with the specific designation of Northamptoni, as a tribute of respect to the noble President of the Royal Society.

Summary.-The fauna of the Wealden, according to the present state of our knowledge, comprises the following Vertebrata:-

Fishes.-About 30 species; of which one belongs to the Cycloid order, 16 are Placoids, and 15 Ganoids.

Reptiles.-Twelve genera of Saurians; and there are indications of four or five not yet established.

One genus of flying reptiles-the Pterodactyle.

Four or five genera of Chelonians.

Of the warm-blooded Vertebrata, bones, supposed to belong to Birds (Palcornithis), are the only vestiges hitherto obtained.

In concluding this imperfect sketch of the fauna and flora of the Country of the Iguanodon, it is impossible not to indulge for an instant in a retrospective glance at the light shed by geological researches during the last quarter of a century, on the physical history of that terra incognita of my early years - the Wealden district of my native county; and I will venture to affirm, that notwithstanding the interest and importance of the organic remains that have been discovered, the palæontology of the fluviatile deposits of the South-east of England is as yet but very imperfectly explored, and that relics

* Sussex, the ancient kingdom of the Regni. 
of the past, more precious than any hitherto obtained, remain to reward the labours of future observers. I would also remark, that the fact of so long a period as nearly thirty years having elapsed between the first discovery of detached teeth, and of a portion of the jaw of an Iguanodon with teeth in place, notwithstanding diligent and constant research, is worthy of especial consideration, as a striking proof of the little reliance that ought to be placed on what is termed negative evidence ; and it suggests the salutary caution, that we should not hastily infer the non-existence of any forms of animated nature in the earlier ages revealed by geology, simply because no vestiges of their organic remains have been detected.

\section{On the Position and General Characters of the Strata exhibited in the Coast Section from Christchurch Harbour to Poole Harbour. By Joseph Prestwich, Jun., Esq., F.G.S.}

I HAVE on former occasions described the eocene strata of Whitecliff Bay and of Alum Bay*. The sections of these two localities show in a remarkable manner the changes there undergone, in the comparatively short distance of twenty miles, by the series of sands and clays forming the Bracklesham Bay beds, and included between the London clay and the Barton clay. I also gave the commencement of the section of the Barton clays at Barton, to show their connection with the upper part of the section at Alum Bay. I have recently had the opportunity of further examining the coast-sections from Barton Cliff to Poole Harbour, with a view to continue the sequence of superposition lower in this more westward portion of the series. This part of the coast was described by Sir Charles Lyell in a paper read before this Society in March 1826. I need not therefore enter into a detailed description of the strata, but will confine myself to the question of the exact position which they bear with reference to the Barton clay, and to a few general observations on their physical conditions. The progress made by the sea in the destruction of the cliffs has also, I believe, brought to light some new features.

In the first place I have, I think, obtained evidence of the existence of the Barton clays to the westward of Christchurch Harbour; consequently the section downwards from them, which I had discontinued at Muddiford, can now be taken up and continued uninterruptedly to Poole Harbour.

Mr. Webster and Sir Charles Lyell have both noticed the sands which underlie the Barton clays at the end of the Barton Cliff near Muddiford. After leaving this cliff, Christchurch Harbour, with its dunes, intervenes for the space of a mile and a half before we reach the cliff at Hengistbury Head. The relation of the strata at this point to those of the Barton cliffs is thereby obscured, and the sequence rendered apparently incomplete.

It may be necessary here again to mention briefly the general characters of the lower part of the Barton clays as exhibited in the cliff east of Muddiford. The extreme abundance of fossils in the upper

\footnotetext{
* Quart. Journ. Geol. Soc. rol. ii. p. 224, and vol, iii. p. 408.
} 